\title{
Incidence of different insect visitors and their relative abundance associated with coriander (Coriandrum sativum) in district Charsadda
}

\author{
Muhammad Usman ${ }^{1,2 *}$, Fazli Amin ${ }^{2}$, Najm-Ul-Saqib ${ }^{1,2}$, Kamran \\ Sohail ${ }^{2}$, Syed Fahad Shah ${ }^{2}$ and Abdul Aziz ${ }^{1}$ \\ 1. Department of Entomology, Bacha Khan University Charsadda, KPK-Pakistan \\ 2. Department of Entomology, The University of Agriculture Peshawar KPK-Pakistan \\ *Corresponding author's email: usman_syn@yahoo.com \\ Citation \\ Muhammad Usman, Fazli Amin, Najm-Ul-Saqib, Kamran Sohail, Syed Fahad Shah and Abdul Aziz. Incidence \\ of different insect visitors and their relative abundance associated with coriander (Coriandrum sativum) in \\ district Charsadda. Pure and Applied Biology. Vol. 7, Issue 2, pp539-546. \\ http://dx.doi.org/10.19045/bspab.2018.70067
}

\begin{tabular}{llll}
\hline \hline Received: 27/02/2018 & Revised: 13/04/2018 & Accepted: 14/04/2018 & Online First: 24/04/2018 \\
\hline \hline
\end{tabular}

\section{Abstract}

Virtually all flowering plants on the earth need pollinators for their pollination. Pollinators provide pollination services to more than 1200 crop species. Here, we analyzed the diversity of pollinators and their relative abundance on coriander (Coriandrum sativum L.) planted at Bacha Khan University Charsadda Agriculture Research farm (BARF). Sampling was done on weekly basis at two time interval from10:00-12:00pm and 03:00-05:00pm. A total of 10 insect species were recorded pollinating coriander from insect orders Diptera, Hymenoptera Lepidoptera and Coleoptera. Pollinator's activities were recorded in peak during the month of April from 10:00-12:00pm. Apis mellifera, Eristalis tenax, Episyrphus balteatus and Megachile spp. showed higher abundance.

Keywords: Coriander; Diversity; Insect species; Pollination; Pollinators

\section{Introduction}

Coriander (Coriandrum sativum L.) belongs to family Apiaceae, is mainly cultivated from its seeds throughout the year [1]. It is one of the 20,000 species of plants in the world which is used for food, cosmetics and other chemicals [2]. Coriander is an excellent multifarious plant [3] and is highly reputed as Ayurvedic medicinal plant, commonly known as (dhanya) in Indo-Pak. It is highly aromatic and has multiple uses in food and industries. All parts of the plant are used for eating. In Pakistan during 2010-2011 coriander was grown on an area of 5900 hectares with seed production of 2600 tons with an average of 0.4 tons per hectares [4] while in Khyber Pakhtunkhwa province the production was 100 tons over an area of 200 hectares.

The role of pollination in agriculture is of vital importance. Without the actions of pollinators, agricultural productivity, our food supply and surrounding landscapes would collapse [5]. There are about 87 crops of the main 124 crops in the world that are dependent on pollinators [6]. Coriander is one of the crops that require pollinators for its production. Its flower produces both hermaphrodite and staminate flowers. The hermaphrodite flowers are completely protandrous with anther 
maturity before the stigma becomes receptive, [7] so it requires the pollen from other flowers with the help of pollinators. [5] Reported that the honeybees are the major pollinators and cross-pollination is estimated to be up to 50 per cent in coriander. According to the observations of several authors [3, 8-10] the flowers of coriander attract many groups of insects, in particular the Diptera, the Coleoptera, and the Hymenoptera. The latter order dominates, represented mainly by the bees, which are among the potential pollinators of this crop. In India, pollinator bees are dominated by the species of Apis spp. The studies on the pollination requirement of coriander crop were made by $[9,11-16]$. There is a gap in the knowledge of insect pollinators in coriander in Pakistan, to fill this gap the present research work is directed to study insect pollinators visiting coriander and to determine their relative abundance.

\section{Materials and methods Experimental site}

This study was conducted at BARF during 2017. Local variety of coriander was sown in the first week of October in single plot size of $5 \times 5 \mathrm{~m}^{2}$ with three replications and each replication was consisted of five rows, each with15 plants, respectively. Row to row and plant to plant distance was maintained as 70 and $30 \mathrm{~cm}$, respectively.

\section{Collection of pollinators}

Different types of pollinators were noticed on coriander flower. Samples were collected with the help of sweep-net and were placed in killing jar having ethyl acetate as killing agent. The collected specimens were then brought into the entomological research laboratory for further research. These collected samples were then counted, and pinned for later species identification.

\section{Data collection}

Data was recorded on weekly basis, at twotime interval from 10am-12pm (Morning) and 3:00-5:00pm (Evening) from flowering stage up to the flowering decline stage. Randomly five plants were observed each for five minutes and the number and species of insects visiting the flowers were recorded for six weeks and their weekly means were calculated $[17,18]$.

\section{Insect identification}

The collected specimens were identified with the help of available literature and by comparison with already identified specimens. After identification, all the pollinator species were properly labeled, pinned and finally deposited in the Insect Museum of the Department of Entomology, The University of Agriculture, Peshawar.

\section{Results \\ List of Insect pollinators visiting coriander}

According to observation of the present study ten insect species foraging coriander. Five species belong to the order Diptera, in which family Syrphidae and Calliphoridae are represented by two species each i.e. Eristalis tenax, Episyrphus balteatus, Calliphora vomitoria (Blue bottle fly) and Lucillia sericata, respectively and one species from the family Sarcophahidae (Sarcophaga bercaea). Hymenoptera is represented by three species, Apis mellifera, ant and Megachile spp. of the families Apidae, Formicidae and Megachilidae, respectively. One each Lepidopterian (Pieris brassicae: Pieridae) and Coleopteran (Coccinella septempunctata: Coccinellidae) were also observed foraging coriander (Table 1).

\section{Average mean population of insect pollinators on coriander}

\section{E. tenax}

Results in (Figure 1) indicated that in W1 the average mean population of insects visiting coriander plant were recorded 2 and 1.5 insects plant ${ }^{-1}$ in morning and evening, respectively. A slight increase in insect pollinators was noted in $\mathrm{W} 2$ and 3 and tends to continue in W4. The number of individual E. tenax reached the peak in W4 where the average mean value reached to 4 and 2.33 insects plant ${ }^{-1}$ in morning and evening and then decreased subsequently. Data in Figure also showed that highest 
number of pollinators was recorded in morning as compare to evening.

Table 1. List of insect pollinators of coriander in farmer's field of district Charsadda

\begin{tabular}{|c|c|c|c|c|}
\hline S. No & Scientific name & Common name & Family & Order \\
\hline 1 & Eristalis tenax & European hover fly & Syrphidae & Diptera \\
\hline 2 & Episyrphus balteatus & Marmalade hover fly & Syrphidae & Diptera \\
\hline 3 & Lucillia sericata & Green bottle fly & Calliphoridae & Diptera \\
\hline 4 & Calliphora vomitoria & Blue bottle fly & Calliphoridae & Diptera \\
\hline 5 & Sarcophaga bercaea & Flesh fly & Sarcophagidae & Diptera \\
\hline 6 & Apis mellifera & European honey bee & Apidae & Hymenoptera \\
\hline 7 & Ant spp & Ant & Formicidae & Hymenoptera \\
\hline 8 & Megachile spp. & leaf cutter bee & Megachilidae & Hymenoptera \\
\hline 9 & Pieris brassicae & Cabbage butterfly & Pieridae & Lepidoptera \\
\hline 10 & Coccinella septumpunctata & Ladybird beetle & Coccinellidae & Coleoptera \\
\hline
\end{tabular}

\section{E. balteatus}

The average mean population of $E$. balteatus on coriander in $\mathrm{W} 1$ was 2.0 insects plant ${ }^{-1}$ in morning while 1.25 insects plant $^{-1}$ in evening. The Average number of insects visiting coriander started increasing in W2 and peaked in W5 in morning after wards a decline in the mean population was observed in W6. The average mean population recorded in W5 was 4 and 2.5 insect plant $^{-1}$ in morning and evening, respectively. Higher average mean population of $E$. balteatus was recorded in morning (Figure 2).

\section{L. sericata}

As previously observed similar pattern of foraging was also observed in L sericata. The insects started visiting in W1 and peaked in W4.Highest average mean population (4 and 2.5 insect plant ${ }^{-1}$ in morning and evening) of insects pollinators was noted in W4 and then declined subsequently both in morning and evening in W5 and 6 (Figure 3).

\section{C. vomitoria}

Data in (Figure 4) revealed no foraging activity of insects in $\mathrm{W} 1$ both in morning and evening. In week 2 the average mean population of insects were 2.0 insect plant $^{-1}$ in morning and linsect plant ${ }^{-1}$ in evening followed by an increase in $\mathrm{W} 3$ and decline in W4.Again an increase in insect pollinators was observed in W5 where the average value recorded in morning and evening was 2.5 and 2 insects plant ${ }^{-1}$, respectively. Same decreasing trend was observed in W6. More average mean population of insect pollinators was recorded in morning

\section{S. bercaea}

S. bercaea started foraging activities in W1 and recorded 1.33 insects plant $^{-1}$ in morning and 1 insect plant ${ }^{-1}$ in evening. An increase in insect pollinators was recorded in W2 and tends to continue up to W6. The number of individual flesh fly reached to peak in W6 where the average mean value reached to 3 in morning while the maximum number i.e. 2.0 insect pollinators plant $^{-1}$ were recorded in w3 and w5 in evening and then decreased subsequently. Data in Figure also showed that highest number of pollinators was recorded in morning as compare to evening (Figure 5). 
Usman et al.

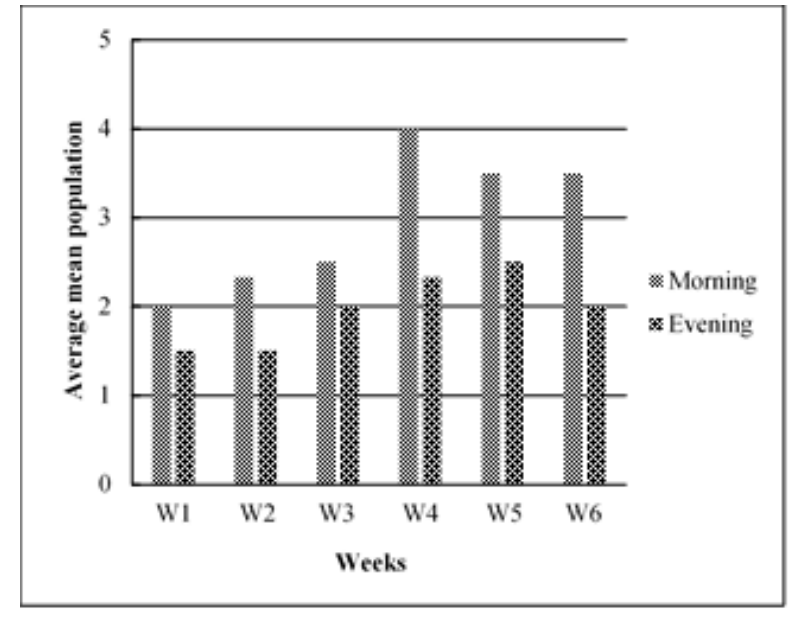

1

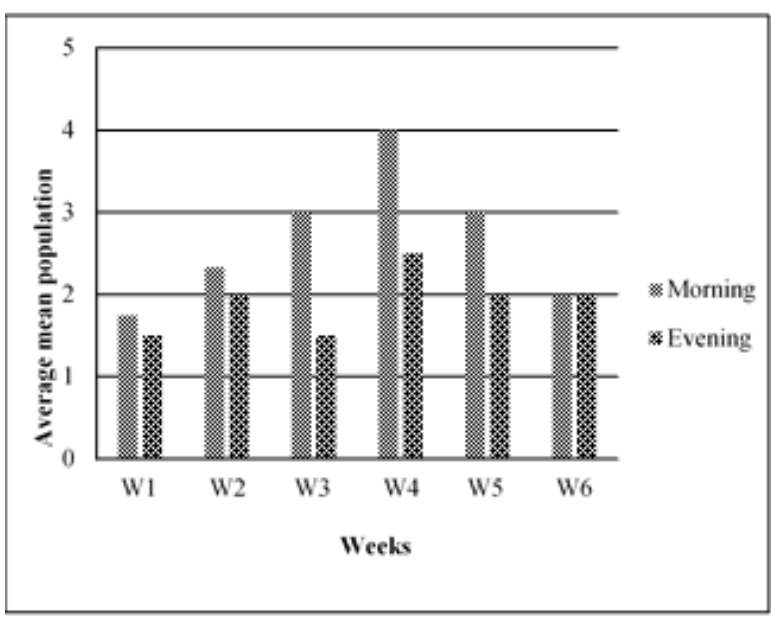

3

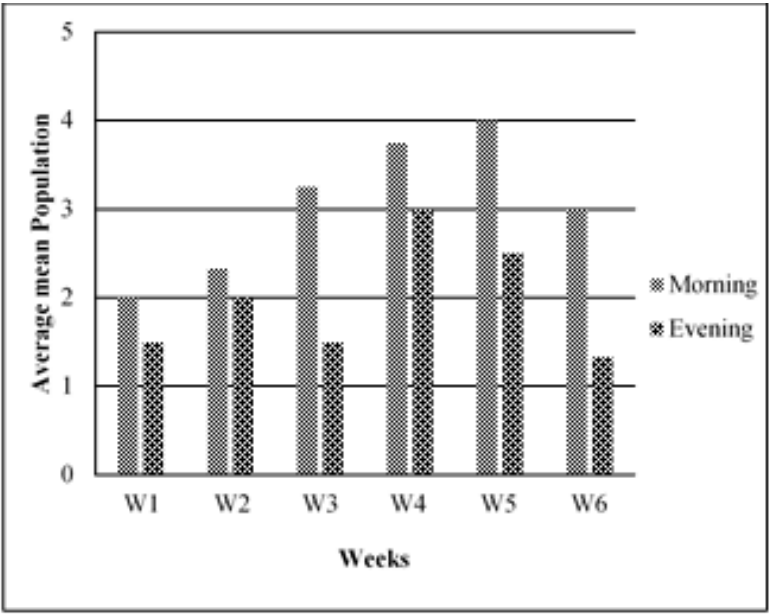

2

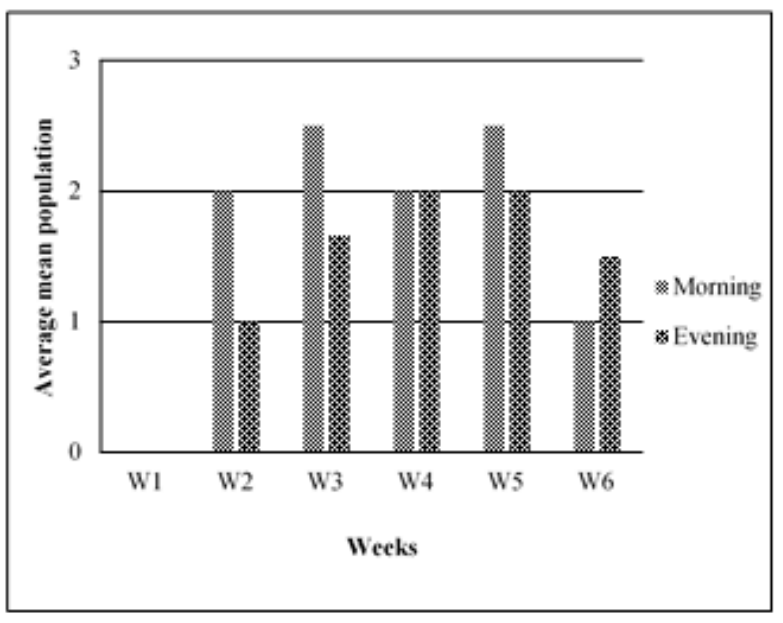

4

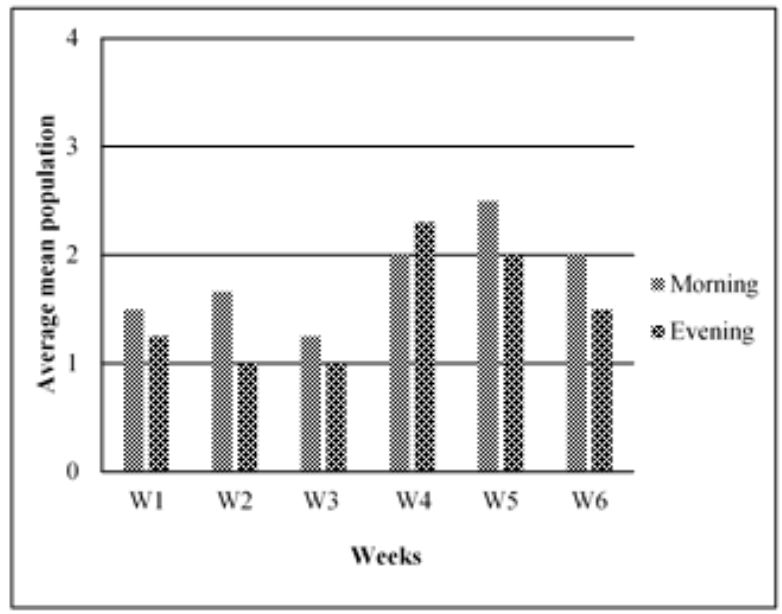

5

Figures 1-5. Average mean population of insect pollinators on coriander plant, 1. E. tenax 2. E. balteatus 3. L. sericata 4. C. vomitoria 5. S. bercaea

\section{A. mellifera}

Figure 6 indicated that in $\mathrm{W} 1$ the average mean population of $A$. mellifera was 2.0 and
1.85 plant $^{-1}$ in evening and morning, respectively. The average mean population of A. mellifera increased in the subsequent 
weeks. Highest average mean population of A. mellifera plant $^{-1}$ was recorded in W5 where the average mean value reached to 4.0 and 3.12 pollinator's plant ${ }^{-1}$ in morning and evening, respectively afterwards decline in population was recorded. Lower average mean population of pollinators was observed in evening as compare to morning time.

Ants

Results on the average mean population of Ants are shown in (Figure 7). The average mean population of ants in W1 was 1.75 and 1.8 insect plant ${ }^{-1}$ in morning and evening, respectively. An increase in ant population was recorded in W2 and 3 and reached to its highest value in W5 where the average mean population of ants in morning and evening was 3.0 and 2.3 insect plant ${ }^{-1}$, respectively and then decline afterwards. In morning time more number of insects pollinators was observed as compared to evening.

\section{Leaf cutter bee}

The average mean population of leaf cutter bee recorded on coriander in W1 was 1 and 2 insect plant ${ }^{-1}$ in morning and evening, respectively. The average value of leaf cutter bee increased in the subsequent weeks in morning and evening. Pollinator population recorded in $\mathrm{W} 4$ and $\mathrm{W} 5$ indicated the highest numbers of insects where the average mean population recorded was 3 and 3.3 insect plant ${ }^{-1}$ in morning and evening respectively and then decreased subsequently. Results in (Figure 8) concluded from overall mean of the data indicated that the lowest numbers of pollinators were recorded in evening.

\section{P. brassicae}

Results in (Figure 9) showed that in W1 the average population of $P$. brassicae visiting the coriander plant was 1.66 and 1.5 plant $^{-1}$ in morning and evening, respectively. An increase in population was recorded in W2 having 2 insects plant ${ }^{-1}$ both in morning and evening with slight decrease in W3 and again increased and reached to highest value in $\mathrm{W} 4$ and 5 where the average number of individuals plant ${ }^{-1}$ were 3.0 and 3.0 in morning, while 2.0 and 1.6 insects plant $^{-1}$ in evening, respectively. In week 6 pollinators population tends to decline both in morning and evening.

\section{C. septempunctata}

Average mean population of $C$. septempunctata visiting coriander plant in W1 was1.5 and 1.25 insect plant ${ }^{-1}$ in morning and evening, respectively. An increasing trend in C. septempunctata mean population was recorded in the coming weeks. The number of individual ladybird beetles in morning reached to peak in W5 with 2.5 insect plant $^{-1}$ while the highest (2.3 insect plant $^{-1}$ ) average mean value in evening was recorded in W4 and then decreased subsequently. Lowest number of pollinators was recorded in evening as compare to morning time (Figure 10).

\section{Discussion}

Pollination is an important phenomenon and insect plays a key role in pollination. In the present study various number of pollinators are noted in which higher number of pollinators belongs to the order Diptera followed by Hymenoptera. Lower number of pollinator's was recorded from the orders Lepidoptera and Coleoptera. In this study $E$. tenax, A. mellifera, $P$. brassicae and $E$. balteatus were recorded abundantly visiting the coriander. Mukherjee et al. [19] reported butterflies, honey bees and lady bugs that serves as important pollinators. These results are also in agreements with the findings of [20] who observed that E. balteatus and A. mellifera works most abundantly as pollinators. [21] Found that $A$. florea, contributing to pollination. [22] From their research it was found that a single honey bee species $A$. mellifera in a minute visits 27.98 flowers. Results of [21] show concurrence with our findings, as they noticed A. florae with a very little prevalence. 


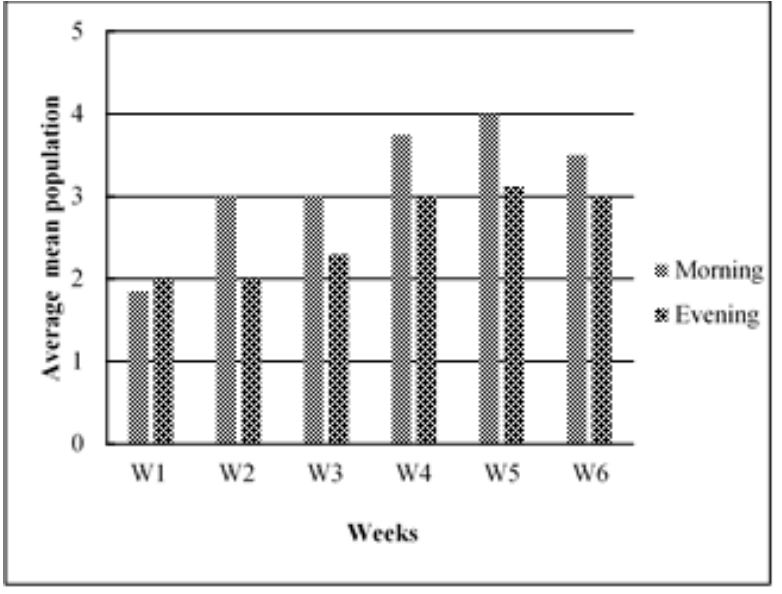

6

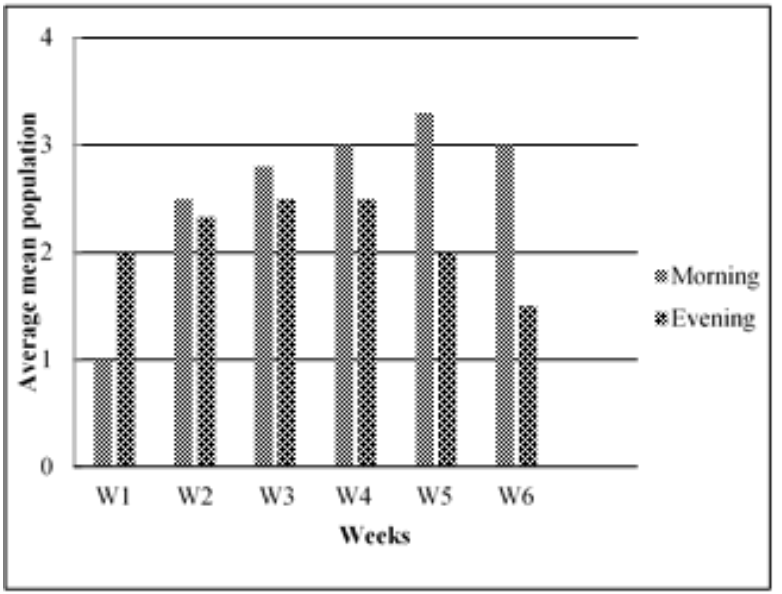

8

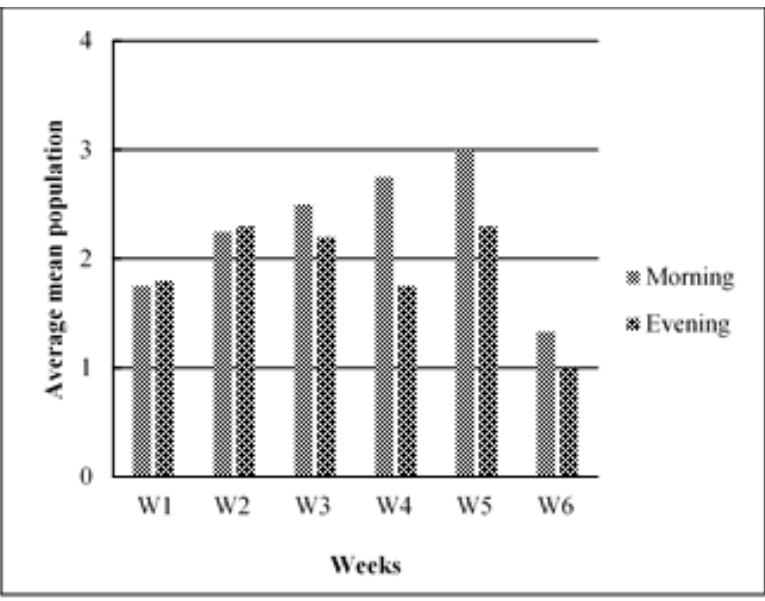

7

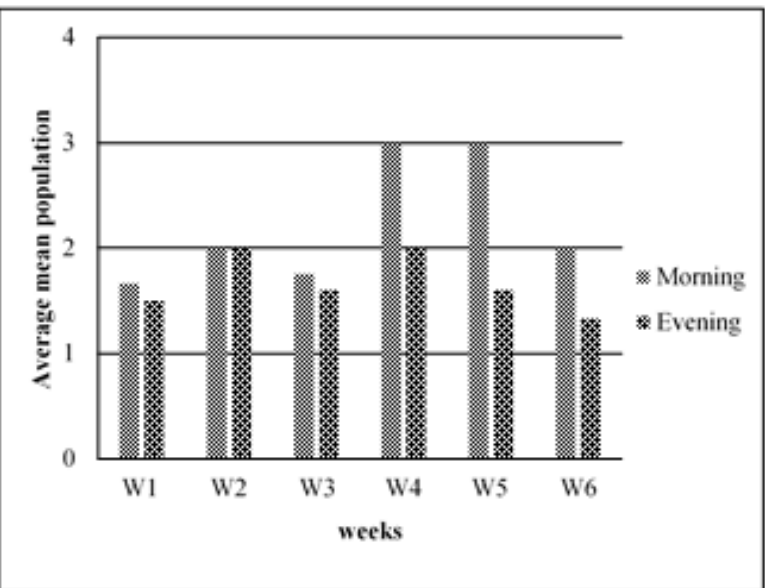

9

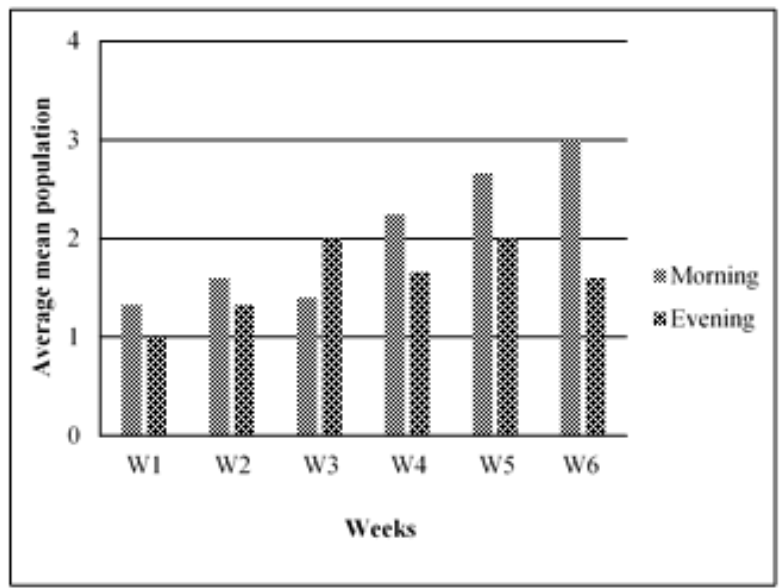

10

Figures 6-10. Average mean population of insect pollinators on coriander plant, 6. $A$. mellifera 7. Ant spp 8. Leaf cutter bee 9. P. brassicae 10. C. septempunctata

Sajjad et al. [20] noticed 14 E. balteatus visited 25 plants in 20 minutes, i.e. they found it most frequently among all other observed insect pollinators. They also found that density of all visiting pollinators were higher in morning i.e. 10:00 am-12:00 pm than evening. Both of their findings have shown resemblance to our study. Visitation time of pollinator insects, generally occur in the morning, related to plant resources, 
especially pollen and nectar availability. Most probably, both availability of pollen and nectar are higher in the morning than in the afternoon and evening. Most bees collect nectar, which provides energy, and pollen, which supplies the protein for larval growth. Among the Syrphidae family (Diptera) the contribution of hoverfly pollination of coriander is probably poor. The low capacity of the Syrphids for transporting pollen is due to the paucity of their hair and the simple morphology of their bristles.

\section{Conclusion and recommendation}

In conclusion, the present findings focus on the insect pollinators visiting the coriander and their relative abundance. Our findings indicate ten insect species foraging coriander with highest number in morning time. It is advised to farmers not to apply insecticide during the month of April on coriander plant as it will adversely affect the insect pollinators. Pollinators can be protected by rational pesticide management tactics. For example, pesticide application if needed should be done in late afternoon to protect the pollinators for high production. Farmers should concern honey bee keepers in order to place bee colonies in their fields to enhance pollination. All those ways are to be adopted, which makes the environment favorable for pollinators like most of Dipterans and Hymenopterans, as these are most frequent pollinators.

\section{Authors' contributions}

Conceived and designed the experiments: $M$ Usman, Performed the experiments: $\mathrm{M}$ Usman \& NU Saqib, Analyzed the Data: F Amin, K Sohail \& SF Shah, Contributed reagents/ materials/ analysis tools: A Aziz \& F Amin, Wrote the paper: M Usman.

\section{References}

1. Mhemdi H, Rodier E, Kechaou N \& Fages J (2011). A supercritical tuneable process for the selective extraction of fats and essential oil from coriander seeds. J Food Engg 105(4): 609-616.

2. Hmamouchi M (1997). Food, aromatic, condimented, medicinal and toxic plants in Morocco. In: Heywood V.H., Skoula M. (Eds.) - Identification of wild food and non-food plants of the Mediterranean region. Chania: CIHEAM-IAMC 89-108.

3. Ricciardelli D'Albore CG \& Intoppa F (2000). Flori e api. The flora visited by Api and dagli other Apoidei in Europe. Calderini Edagricole. Bologna pp 110.

4. MINFAL (2010). Agricultural statistics of Pakistan. Ministry of Food, Agriculture. Livestock (Economic Wing), Islamabad.

5. Ramanujam S, Joshi BS \& Saxena MVL (1964). Extent and randomness of cross pollination in some umbelliferous spices of India. Indian J Genetics 24: 62-67.

6. Klein MA, Vaissière BE, James HCL, Cunningham SA, Kremen and $\mathrm{C}$ \& Tscharntke $T$ (2007). Importance of pollinators in changing landscapes for world crops. Proceeding Biol Science 274: 303-313.

7. Nemeth E \& Szekely G (2000). Floral biology of medicinal plants. Apiaceae Sp. Int J Hort Science 6(3): 133-136.

8. Shelar DG \& Suryanarayana MC (1981). Preliminary studies on pollination of coriander. Indian Bee $J$ 43(4):110-111.

9. Baswana KS (1984). Role of insect pollination on seed production in coriander and funnel. J Indian Hort 31(2): 117-118.

10. Sinacori A, Sinacori M, Oliveri E \& Carrubba A (2009). Api e pronubisel vaticinella produzione di Coriandrum sativum L. Apoidea 6(3): 155-161.

11. Glukhov MM (1955). Honey plants. Izd-vo-Selkhoz Lit-ry. 512 pp.

12. Hussain MH \& Abdel-Aal, SA (1982). Wild and honeybees as pollinators of 10 plant species in Assiut area. J Appl Entomolgy 93(4): 342-346.

13. Sethi RK (1999). Effect of honeybee (Apis sp.) pollination on the yield of coriander. Thesis submitted to Department of Entomology, College of Agriculture, Orissa University of Agriculture and Technology, Bhubaneswar, ORISSA (INDIA). 
14. Khalid A Tamin A \& Mohammed SK (2008). Study the role of honeybee pollination of Coriandrum sativum. $J$ Apic Res 4:72-74.

15. Anonymous (2010). Annual report of the All India Co-ordinated Research Project on honey bees and pollinators, Rajendra Agric Uni, Pusa pp 55-67.

16. Singh H, Swaminathan R \& Hussain $T$ (2010). Plant products on pollinators of coriander. J Biopes 3: 208-211.

17. Patil PN \& Pastagia JJ (2016). Effect of bee pollination on yield of coriander, Coriandrum sativum Linnaeus. International J Plt Protection 9(1): 7983.

18. Bendifallah L, Louadi K \& Doumandji S (2013). Bee fauna potential visitors of coriander flowers Coriandrum sativum L. (Apiaceae) in the Mitidja area (Algeria). J Apic Sci 57(2): 59-69.
19. Mukherjee S, Mandal A, Gupta S \& Datta AK (2013). Pollination events in Nigella sativa L. International $J$ Research 4(3): 342-344.

20. Sajjad A, Saeed S \& Masood A (2008). Pollinator community of onion (Allium cepa L.) and its role in crop reproductive success. Pak J Zool 40(6): 451-456.

21. Ali T \& Ali SI (1989). Pollination biology of Calotropis procera subsp. hamiltonii (Asclepiadaceae). PhytonHorn (Austria) 29(2): 175-188.

22. Douka C \& Fohouo FHT (2013). Foraging and pollination behavior of Apis mellifera adansonii L. (Hymenoptera, Apidae) on Phaseolus vulgaris (Fabaceae) flowers at Maroua, Cameroon. Inter Res J Plt Sci 4(2): 4554. 